\title{
Field Investigation on Sub-clinical Mastitis in Cows in Different areas of Barisal district in Bangladesh
}

\author{
Mirza Mienur Meher ${ }^{1 *}$, Aliul Hasan ${ }^{2}$, Marya Afrin ${ }^{3}$ \\ ${ }^{l}$ Department of Microbiology and Public Health, Faculty of Animal Science and Veterinary Medicine, Patuakhali Science and Technology \\ University, Patuakhali, Bangladesh. \\ ${ }^{2}$ Faculty of Animal Science and Veterinary Medicine, Patuakhali Science and Technology University, Patuakhali, Bangladesh \\ ${ }^{3}$ Department of Anatomy and Histology, Faculty of Veterinary Science, Bangladesh Agricultural University, Mymensingh-2202, Bangladesh \\ A R T I C L E I N F O \\ A B S T R A C T \\ Research Article \\ Received 07 April 2018 \\ Accepted 04 June 2018 \\ Keywords. \\ Investigation \\ Sub-clinical \\ Mastitis \\ Cows \\ Barisal \\ *Corresponding Author: \\ E-mail: mienur@pstu.ac.bd \\ In every year, Subclinical mastitis (SCM) frequently occurs and results huge economic \\ losses in livestock industry of Bangladesh. This study was redacted to estimate the \\ present status of SCM in cow in selective area of Barisal district. For determining sub- \\ clinical mastitis, a total of 152 milk samples of clinically suspected cows were subjected \\ to White Side Test (WST) and Surf Field Mastitis Test (SFMT). Specifically, the milk \\ samples of each individual cows which were positive to both WST and SFMT considered \\ as SCM indicating $35.52 \%$ prevalence. Other than the local breed cows, the cross bred \\ cows showed significantly higher prevalence, is $47.06 \%$. In consideration to age \\ variation, highest prevalence was observed at 5 to 7 years of age in both types where \\ cross breed was $54.71 \%$ and $36.67 \%$ for local breed cows. Though highest prevalence \\ was recorded as $34.78 \%$ in $2^{\text {nd }}$ parity of local breed cows but the cross breed cows \\ showed highest prevalence $54.55 \%$ in their $3^{\text {rd }}$ parity. Afterward, non-pregnant cows \\ showed the insignificantly higher prevalence $(41.06 \%)$ than pregnant cows were $26.32 \%$. \\ Additionally, this study reported that the cross breed cows yielding more than 10 liters of \\ milk (prevalence was $61.54 \%$ ) were more prone to SCM than the others and also $>5$ to 10 \\ liters milk producing local breed cows (prevalence was $31.03 \%$ ) were more susceptible to \\ SCM than others. In a short, this study revealed that high milk yielding cross breed cows \\ are more likely to SCM after their $3^{\text {rd }}$ calving.
}

DOI: https://doi.org/10.24925/turjaf.v6i9.1159-1162.1957

\section{Introduction}

Mastitis is now one of the major threats for dairy industry due to huge economic losses from reduced milk production with increased treatment costs, labor cost and finally to death or premature culling (Miller et al., 1993). In Bangladesh, it has been estimated that around 122.6 million taka (US \$2.11 million) losses were occurred annually due to reduced milk production alone caused by subclinical mastitis (Kader et al., 2003). As was reported that the prevalence of SCM was 29\% (Islam et al., 2011) to $51.8 \%$ (Tripura et al., 2014) in Bangladesh based on WST and SFMT. A lot of etiological agents have been involved in mastitis in dairy animal including bacteria, mycoplasma and yeast pathogens (Egwu et al., 1994). Staphylococcus sp. is the most frequent etiological agents that cause clinical and subclinical mastitis in cows whereas commonly isolated pathogens are $S$ aureus and Escherichia coli (Contreras et al., 2003). Besides this, some predisposing factors such as pendulous udder with long teats, larger size of teat orifice in high yielding cows, traumatic injuries, poor management and hygiene, teat injuries and faulty milking machines are known to hasten the entry of infectious agents and the course of the disease (Majic et al., 1993). Infection rate is more in successive lactation than the first lactation while exotic and crossbred cows are more prone to mastitis. Physico-chemical, pathological with bacteriological changes in milk and glandular tissue have been commonly implicated with clinical mastitis (CM) (Samad, 2008). Whereas, the Sub clinical mastitis as there were no clinical signs only instead there is an increase in somatic cell counts of the milk (Radostits et al., 2000). Singh (1988) reported, more than three times losses due to SCM as compared to clinical mastitis $(\mathrm{CM})$. The $\mathrm{CM}$ can easily be detected by inspection of udder and or systemic signs. On the other hand, diagnosis of subclinical mastitis is problematic and can be done by various methods, based on physicchemical changes of milk and cultural isolation of organisms (Emanuelson et al., 1987). However, indirect tests viz. California Mastitis Test (CMT), White Side Test (WST), Surf Field Mastitis Test (SFMT) etc. can be 
considered as simple, easily applicable tests without requiring any sophisticated laboratory equipment. Maintaining hygiene with Proper milking procedure might be the easiest and most economical way to control of mastitis (Hutton et al., 1990). This test was undertaken to determine the prevalence of mastitis in Barisal district with antimicrobial efficacy.

\section{Materials and Methods}

The study was carried out during the period of November, 2016 to April, 2017 (for 06 months) in different area of Barisal district of Bangladesh. In this study, most of the suspected lactating ones were considered to take milk samples. All the instruments were sterilized that used for sample collection and separate set of instruments were used for each individual case in a day. Cross and local breeds are available among dairy animals. Extensive management system with ground muddy floor including little amount of concentrate feed were frequently practiced in study areas.

\section{Physical Examination of Animal and Milk Sample}

Physical condition of udder, body temperature, pulse rate, appetite and posture etc. were observed by visual examination of the cows. Different body parts and systems of suspected cows were examined by different methods described by Kelly (1979) and Samad (1988). Udders of the suspected animals were examined by different ways which were described by Islam et al. (2010). Besides this, all the milk samples were considered for physical examination with naked eyes and organoleptic tests immediately after collection.

\section{Collection of Clinical Data}

All the clinical data from the owners and persons exclusively related with the affected animals were collected by using a questionnaire which was formulated with considering the criteria described by Thrusfield (2005).

\section{Indirect Tests for Detection of Mastitis}

All the tests were performed at field condition immediately after collection of milk.

White Side Test (WST): For detection of subclinical mastitis the WST was practiced according to the procedure which was narrated by Kahir (2006). In this test well mixed five drops of suspected milk samples were placed on a glass slide bearing a dark background and then $20 \mu \mathrm{l}$ of $4 \% \mathrm{NaOH}$ solution were mixed. And the mixture was stirred frequently with a sterile toothpick for 20-25 seconds. The result and grading of WST was determined as well as Kahir (2006).
Surf Field Mastitis Test (SFMT): In this test, $2 \mathrm{ml}$ milk was drawn into a black paddle cup and $2 \mathrm{ml}$ surf solution $(4 \%$ solution of Surf Excel ${ }$, Uniliver, Bangladesh) was properly mixed by gentle circular motion of the paddle for few seconds. The reaction developed almost within 30 seconds and immediately result was scored as $1+, 2+$ and $3+$ like WST. This test was performed and scored following the method described by (Muhammad et al., 1995).

\section{Results and Discussion}

In this study, a total of 152 cases were faced and all were sick dairy species. Among them 83 samples were showed positive to both or not WST and SFMT. The samples which were showed positive to both WST and SFMT are considered as mastitis positive sample. The prevalence of SCM in lactating cows were $35.52 \%$. This finding was closely associated with Islam et al. (2010) who reported $36.46 \%$ prevalence in lactating cow. Moreover, Kader et al. (2002) reported 46.6\% SCM in cross-bred lactating cows in Bangladesh whereas Prodhan et al. (1996) reported a lower prevalence (15.8\%) in Baghabari milk shed area of Bangladesh. Subsequently, Islam et al. (2011) found 29\% and Tripura et al. (2014) reported $51.8 \%$ prevalence in Bangladesh. Some causes likewise, breed variation, management systems and tests used for screening of milk samples were responsible for these dissimilarities on prevalence rates of SCM. Furthermore, prevalence of SCM was significantly $(\mathrm{P}<0.01)$ higher in cross breed $(47.06 \%)$ than in local breed cow, 26.19\% (Table 1). In this study, prevalence of cross breed cow was higher than the finding of Islam et al. (2011) that is $36.36 \%$ but in local breed cow, this is almost similar calculating as $24.61 \%$ at rural area of Tangail in Bangladesh. On the other hand, this result is similar with the findings of Rahman et al. (1997) who observed higher frequency of sub-clinical mastitis in cross breeds. Cross breed cows produce more milk than the local zebus. Having large size, long, and pendulous udder in cross breed cow might have picked up more infection resulting higher rate of infection (Roy et al., 1993). But the result may vary due to improper hygienic condition and ignorance of the farmer and also the limited stock of cross breed.

In the aspects of age variation, the highest prevalence rate was recorded as $54.17 \%$ and $36.67 \%$ respectively in cross breed and local breed cows having the age between $>5$ to 7 years which was not significant $(\mathrm{P}>0.05)$ (Table 2 ). It indicates that during this age, the dairy cows are in their optimum milk production which acts as an important factor for occurring SCM. These observations partially support with the findings of Rahman et al. (2009) and the result may have a little bit of variation with others observations may be due to different management system.

Table 1 Prevalence of mastitis in different types of cow

\begin{tabular}{l|cccc}
\hline Types of cow & No. of sample tested & No. of positive sample & Prevalence (\%) & P-value \\
\hline Cross breed & 68 & 32 & 47.06 & \\
Local breed & 84 & 22 & 26.19 & 0.007 \\
\hline Total & 152 & 54 & 35.53 & \\
\hline
\end{tabular}

Highly significant at $1 \%$ level $(\mathrm{P}<0.01)$ 
Table 2 Age wise prevalence of SCM in dairy cows

\begin{tabular}{|c|c|c|c|c|c|c|c|c|}
\hline \multirow{2}{*}{ Age (Year) } & \multicolumn{4}{|c|}{ Cross breed } & \multicolumn{4}{|c|}{ Local breed } \\
\hline & NST & NPS & $\mathrm{PP}(\%)$ & $\mathrm{P}$ & NST & NPS & $\mathrm{PP}(\%)$ & $\mathrm{P}$ \\
\hline 2 to 3 & 11 & 5 & 45.45 & & 21 & 5 & 23.81 & \\
\hline$>3$ to 5 & 23 & 12 & 52.17 & & 21 & 4 & 19.05 & \\
\hline$>5$ to 7 & 24 & 13 & 54.17 & 0.298 & 30 & 11 & 36.67 & 0.410 \\
\hline$>7$ to $\geq 8$ & 10 & 2 & 20 & & 12 & 2 & 16.67 & \\
\hline Total & 68 & 32 & 47.06 & & 84 & 22 & 26.19 & \\
\hline
\end{tabular}

NST: No. of sample tested, NPS: No. of positive sample, PP: Percentage (\%) of prevalence, P: P- value, Significant at $5 \%$ level (P<0.05).

Table 3 Parity wise prevalence of SCM in cows.

\begin{tabular}{|c|c|c|c|c|c|c|c|c|}
\hline \multirow{2}{*}{ Parity (Lactation) } & \multicolumn{4}{|c|}{ Cross breed } & \multicolumn{4}{|c|}{ Local breed } \\
\hline & NST & NPS & $\mathrm{PP}(\%)$ & $\mathrm{P}$ & NST & NPS & $\mathrm{PP}(\%)$ & $\mathrm{P}$ \\
\hline $1^{\text {st }}$ & 17 & 7 & 41.18 & & 18 & 4 & 22.22 & \\
\hline $2^{\text {nd }}$ & 15 & 7 & 46.67 & & 23 & 8 & 34.78 & \\
\hline $3^{\text {rd }}$ & 22 & 12 & 54.55 & 0.84 & 19 & 5 & 26.32 & 0.709 \\
\hline $4^{\text {th }}$ & 14 & 6 & 42.86 & & 24 & 5 & 20.83 & \\
\hline Total & 68 & 32 & 47.06 & & 84 & 22 & 26.19 & \\
\hline
\end{tabular}

NST: No. of sample tested, NPS: No. of positive sample, PP: Percentage (\%) of prevalence, P: P- value, Significant at $5 \%$ level (P<0.05).

Table 4 Occurrence of mastitis on different reproductive stage.

\begin{tabular}{l|cccc}
\hline \multicolumn{1}{c|}{ Pregnancy status } & No. of sample tested & No. of positive sample & Percentage & P-value. \\
\hline Non Pregnant and lactating & 95 & 39 & 41.06 & \\
Pregnant and lactating & 57 & 15 & 26.32 & 0.066 \\
\hline Total & 152 & 54 & 35.53 & \\
\hline
\end{tabular}

Significant at $5 \%$ level $(\mathrm{P}<0.05)$

In consideration to parity, SCM occurs in different stages of lactation. Parity plays an important role in causing mastitis. In cross breed cows of $3^{\text {rd }}$ parity, prevalence was $54.55 \%$ insignificantly $(\mathrm{P}>0.05)$ higher than other parity where lowest prevalence $(41.18 \%)$ was in $1^{\text {st }}$ parity (Table 3.). This result agrees with the findings of Rasool et al. (1985) who reported an upsurge prevalence of SCM associated with progressive stage of parity. However, in local breed cows, the highest prevalence $\left(34.78 \%\right.$ ) was recorded in $2^{\text {nd }}$ parity but the lowest was $20.83 \%$ (Table 3.) in $4^{\text {th }}$ parity that was insignificant $(\mathrm{P}>0.05)$ than other parity. This finding is very much close to Sing et al. (1988) where he stated that the highest prevalence rate of SCM was in $2^{\text {nd }}$ parity than others. The highest prevalence $(41.06 \%)$ of SCM was found in non-pregnant cows and was insignificantly $(\mathrm{P}>0.05)$ higher than pregnant cows where prevalence was $26.32 \%$ (Table 4). These findings are almost close to Biswas et al. (2017) where he stated that the non-pregnant cows $(55.55 \%)$ are more prone to infection than pregnant cows $(46.43 \%)$. In pregnant and lactating animals, the amount of milk production is reduced due to lower amount of prolactin release and lower nutritional level because fetus takes a great part on nutrition. Low milk production is less prone to mastitis (Nulin et al., 1989). For determining the prevalence of SCM related to milk yield the cross breed and local breed cows were grouped into three (Table 5). Though, the highest prevalence was $61.54 \%$ in cross breed cows yielding more than 10 liters of milk but the local breed cows having milk yield between $>5$ to 10 liters showed insignificantly $(\mathrm{P}>0.05)$ highest prevalence $(31.03 \%)$ than other groups. This observation is considerably similar with the report of Islam et al. (2011) and Tripura et al. (2014).

\section{Conclusion}

All over the Bangladesh, mastitis outbreak is very common and it dramatically increases the production cost in livestock. Especially high yielding cross breed cows of 5 to 7 years ages with $3^{\text {rd }}$ parity are more susceptible which may leads to threat for our emerging dairy industry. Early detection and improve management system can reduce its prevalence. A well research on determining the antimicrobial properties and genetic analysis of the causative agents may contrive to subdue the mastitis in near future.

\section{References}

Biswas D, Sarker T. 2017. Prevalence of sub-clinical mastitis at banaripara upazilla, barisal. Bangladesh Journal of Veterinary Medicine, 15 (1): 21-26.

Contreras A, Luengo C, Sanchez A, Corrales JC. 2003. The role of intramammary pathogens in dairy goats. Livestock Production Science, 79: 273-283.

Egwu GO, Zaria LT, Onyeyili PA, Ambali AG, Adamu SS, Birdling M. 1994. Studies on the microbiological flora of caprine mastitis and antibiotic inhibitory concentration in Nigeria. Small Ruminant Research, 14: 233-239.

Emanuelson U, Olsson T, Holmberg O, Hageltorn M, Mattila T, Nelson L, Astrom G. (987. Comparison of some screening tests for detecting mastitis. Journal of Dairy Science, 70: 880-886.

Hutton CT, Fox LK and Hancock DD. 1990. Mastitis control practices: differences between herds with high and low somatic cell counts. Journal of Dairy Science,73: 1135.

Islam MA, Islam MZ, Islam MA, Rahman MS, Islam MT. 2011. Prevalence of subclinical mastitis in dairy cows in selected areas of Bangladesh. Bangladesh Journal of Veterinary Medicine 9(1): 73-78. 
Islam MA, Rahman AKMA, Rony SA, Islam MS. 2010 Prevalence and risk factors of mastitis in lactating dairy cows at Baghabari milk shed area of Sirajganj. Bangladesh Journal of Veterinary Medicine 8(2): 157-162.

Kader MA, Samad MA, Saha S. 2003. Influence of host level factors on prevalence and economics of subclinical mastitis in dairy cows in Bangladesh. Indian Journal of Dairy Science, 56: 235-240.

Kahir MA. 2006. A Cross sectional epidemiological study on subclinical mastitis of dairy cows in Sylhet. MS thesis, Department of Medicine, Bangladesh Agricultural University, Mymensingh.

Kelly WR. 1979. Veterinary Clinical Diagnosis, Second Ed.1974. Bailliere, Tandall and Cassel Ltd. London.39-102.

Majic B, Jovanovic BV, Ljubic Z, Kukovics S. 1993. Typical problems encountered in Croatia in the operation of goats milking machines. Proceedings of the 5th Internacional symposium on machine milking of small ruminants. Budapest, Hungary. pp. 377-379.

Miller GY, Bartlett PC, Lance SE, Anderson J, Heider LE. 1993. Costs of clinical mastitis and mastitis prevention in dairy herds. Journal of the American Veterinary Medical Association, 202: 1230-1236.

Muhammad G, Athar M, Shakoor A, Khan MZ, Fazal-urRehman, Ahmad MT. 1995. Surf Field Mastitis Test: An inexpensive new tool for evaluations of wholesomeness of fresh milk. Pakistan Journal of Food Science 5: 91-93.

Nulin AM, Paape MJ, Nickerson SC. 1989. Comparison of phagocytosis and chemiluminescence by blood and mammary gland neutrophils from multiparous and nulliparous cows. American Journal of Veterinary Research 9: 172-177.

Prodhan MAM, Kamal AHM, Mahbub- E- Elahi ATM. 1996. Prevalence of sub-clinical mastitis in cows of Baghabari Milkshed area. Bangladesh Veterinary Journal, 30: 59-60.
Radostits OM, Gay CC, Blood DC, Hinchcliff KW. 2000. Mastitis. In: Veterinary Medicine. A Textbook of the Diseases of Cattle, Sheep, Pigs, Goats and Horses. 9th Edn, W B Saunders Co. Philadelphia, USA. pp. 603-612.

Rahman MA, Bhuiyan MMU, Kamal MM, Shamsuddin M. 2009. Prevalence and risk factors of mastitis in dairy cows. Bangladesh Veterinary Journal, 26: 54-60.

Rahman MS, Nooruddin M, Rahman MM. 1997. Prevalence and distribution of mastitis in cross-bred and exotic dairy cows. Bangladesh Veterinary Journal, 14: 1-4.

Rasool G, Jabbar MA, Kazi SE, Ahmed A. 1985. Incidence of subclinical mastitis in Nili-Ravi buffaloes and Sahiwal cows. Pakistan Veterinary Journal, 5: 76-78.

Roy SK, Pyne AK, Maitra DN. 1993. Studies on teat size and lactation number in relation to incidence of sub- clinical mastitis in some herds of crossbred cows. Indian Veterinary Journal, 70: 677-678.

Samad MA. 1988. Veterinary Clinicial Guide. 2nd edn., LyricEpic Prokasoni, BAU Campus, Mymensingh, pp. 572-580.

Samad MA. 2008. Animal Husbandry and Veterinary Science, volume II, LEP pub no.11, Bangladesh Agricultural University campus, Mymensingh.

Singh KB, Baxi KK. 1988. Studies on the incidence and diagnosis of sub-clinical mastitis in milch animals. Indian Veterinary Journal, 47: 723-729.

Thrusfield MV. 2005. Criteria for Success of Questionnaire. In: Veterinary Epidemiology. 3rd edn, Oxford, UK: Blackwell Science. P. 189-213.

Tripura TK, Sarker SC, Roy SK, Parvin MS, Sarker RR, Rahman AKMA, Islam MT. 2014. Prevalence of subclinical mastitis in lactating cows and efficacy of intramammary infusion therapy. Bangladesh Journal of Veterinary Medicine, 12 (1): 55-61.

Unakal CG, Kaliwal BB. 2010. Prevalence and antibiotic susceptibility of Staphylococcus aureus from bovine mastitis, Veterinary World. 3(2): 65-67. 